\title{
Prevention of domestic child accidents: an educational intervention conducted by Speech Therapy trainees in a Family Health Care Unit
}

\author{
Edinalva Neves Nascimento ${ }^{1}$ \\ https://orcid.org/0000-0002-8154-0716 \\ Sandra Regina Gimeniz-Paschoal ${ }^{1}$ \\ https://orcid.org/0000-0003-0330-132X \\ Luciana Tavares Sebastião' \\ https://orcid.org/0000-0002-1475-4837
}

Universidade Estadual Paulista "Júlio de Mesquita Filho", Marilia, São Paulo, Brasil.

Conflict of interests: Nonexistent

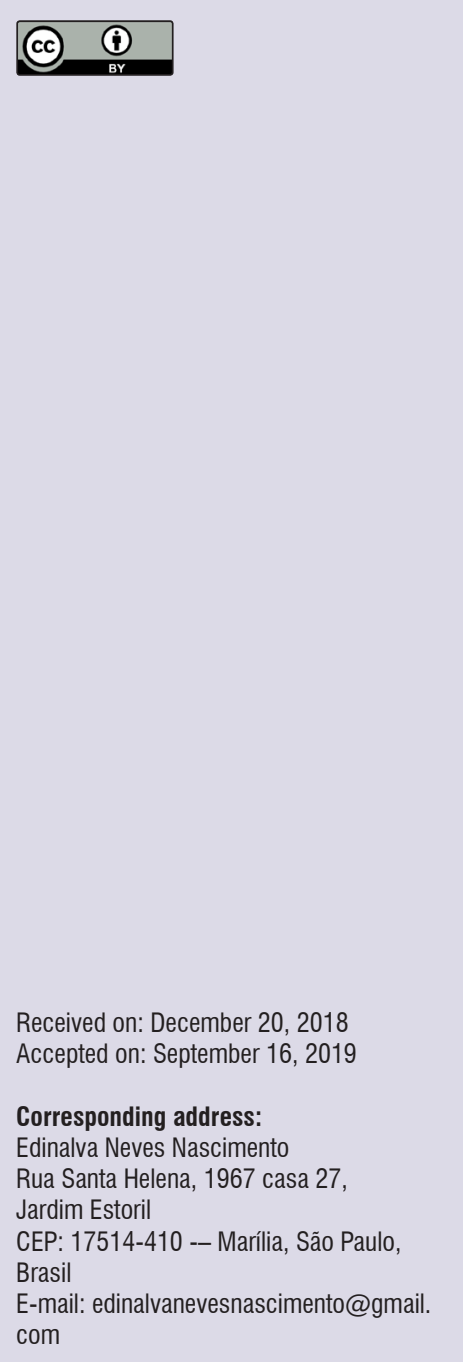

\section{ABSTRACT}

Purpose: to check the effect of an educational intervention on the prevention of domestic child accidents, carried out by Speech Therapy trainees.

Methods: an interventional research that uses primary research data. The action was done by two interns of Speech Therapy with 30 caregivers of children who attended a Family Health Unit. For the carrying out of the educational intervention, two pictures with images which represented objects and situations of risk of accidents were used. Two interview scripts were elaborated, which allowed to identify the caregivers' personal data and their knowledge about the risks of child accidents in the domestic environment before and after carrying out of the educational intervention.

Results: before the educational action, the caregivers identified 187 situations for child accidents, and after the intervention, 215 dangers were identified. Among the 30 caregivers who participated, 23 had significant changes in their answers and seven did not have any change in their knowledge. The main change was in relation to "Accidental poisoning-intoxication by exposure to harmful chemicals" and "The impact caused by an object thrown, projected or falling".

Conclusion: the intervention promoted an increase in the participants' correct reports, and it can be incorporated to the actions of accidents prevention carried out by the trainees and professionals of Speech Therapy who work in basic healthcare.

Keywords: Speech, Language and Hearing Sciences; Accident Prevention; Disease Prevention; Primary Health Care; Health Education 


\section{INTRODUCTION}

The International Classification of Diseases (ICD 10) defines accidents and violence as the external causes of morbidity and mortality. The accidents encompass falls, cuts, poisoning, drowning, burns, traffic accidents, among others ${ }^{1}$.

The intoxications, especially by medical drugs, are also kinds of accidents that occur among children². In children, it is possible to notice also the occurrence of accidents since the first years of life, being common the falls, cuts, and burns ${ }^{3}$. Prospective research carried out in Pelotas, Rio Grande do Sul, with 11,315 children described the incidence of accidents in fouryear-old children and below, and in that study, the falls were the most frequent causes, followed by cuts and burns. Concerning the age, the child accidents occur mainly between two and five years old (42.4\%), being observed also at the ages between six and nine (37.4) and between zero and one (20.3\%) $)^{4}$. Between zero and nine years old (15.6\%) and between 10 and 19 (17.7\%) can also be identified ${ }^{5}$.

The domestic environment is a frequent place for the occurrence of accidents, especially falls, electric shocks, collisions, cuts, burns, slipping, airflow obstructions, and intoxications ${ }^{6}$. Speaking specifically about burns, the risky situations which enable their occurrence at home are the stove, the iron, pans, hot food, matches, cigarette lighters, as well as chemical or flammable products ${ }^{7}$.

A study conducted with 111 children at the ages of 14 and below in the city of Tubarão, in Santa Catarina, showed that 50 of them had the face affected, especially by scald (water, oil, coffee, milk, tea, and other hot foods) and fire (alcohol explosion or direct flame $)^{8}$. When the burns reach the face and/or neck, they can affect deglutition, breathing, speech articulation, chewing, and facial miming .

A study carried out in Montes Claros, Minas Gerais, with the aim of identifying and describing the home accidents in childhood, showed that rarely the families identify the risky situations which cause the accident to the children inside their homes. It justifies the need of carrying out activities of education in health along with the population, in the sense of maximizing the identification of risks and the procedures for protection against accidents ${ }^{7}$.

Parents and/or responsible for the children are an important target public for educational actions about prevention of child accidents, in order to make them know the risks that can possibly be found in domestic environment and promote safe and protective behavior towards children ${ }^{6}$.

The strategies for preventing child accidents can be carried out by the medical doctor, especially the pediatrician ${ }^{10}$. However, any health professional can carry out and/or participate in educational actions of prevention about this issue, if they have the knowledge or experience.

A study with 52 medical professionals, social assistants, psychologists, nurses, nursing technicians, and nursing auxiliaries in an urgency and emergence service in Sorocaba, São Paulo, demonstrated that it is still necessary to have professional qualification in order to work especially in preventing domestic accidents ${ }^{11}$.

A previous study conducted in a child school with the aim of describing an intersectoral of child accident prevention widened the knowledge of the teacher and the children who participated in the action ${ }^{12}$. Besides the school, the speech therapist could also conduct educational activities of accident prevention in primary health care units ${ }^{13}$.

The participation of the speech therapist in the educational actions is ratified by the fact that the injuries commonly affect the head, face, and neck, compromising the speech, language, voice, hearing, deglutition, and breathing, among other functions of speech therapeutic action.

Thus, it is necessary to avoid the injuries, conducting studies of prevention of child accidents, especially by speech therapists who work in primary health care, or even by interns of Speech Therapy who perform their formation activities in this scenery.

In this perspective, the aim of this study was to verify the effect of an educational intervention about prevention of domestic child accidents, conducted by Speech Therapy trainees.

\section{METHODS}

This proposal was approved by the Committee of Ethics in Research of the Paulista State University "Júlio de Mesquita Filho", under the Protocol 2544/2008. It is an interventional research which uses primary research data $^{14}$.

The study was conducted in a Basic Health Unit with Family Health Strategy (UBSF), located in the urban zone of a municipality of the Midwest of São Paulo State, Brazil, with 237,130 inhabitants and a Municipal Human Development Index (MHDI) of $0.798^{15}$.

Firstly, the nurse of the managing trio of UBSF was contacted, in order to check the applicability of the 
study. With her consent, the project was analyzed by the Municipal Division of Evaluation in Research (DIMAP) of the Municipal Secretary of Health, which authorized the research in the Municipal Health Network.

\section{Elaboration of the instruments of data collection and preparation of educational materials}

Two instruments were elaborated for the data collection (interview scripts) with open questions.

The first one contained questions about personal characteristics of the participants (education level, marital status, and profession) and the visit to the health care unit and had four questions: 1) Has any child ever had an accident in your house? 2) If yes, how was it? 3) Looking at the picture (showing the risky situation), what are the dangers of accidents with children you can identify? 4) Would you like to make any other remark?

The second interview script did not contemplate items related to participants' personal aspects and of the visit, but also presented four questions: 1) Looking at the picture again, what do you identify as danger? 2) Among the dangers discussed, which ones can (could) you see in your house or in relatives' or friends' houses? 3) What changes would you make in the kitchen, in order to prevent children from having an accident? 4) What do you think about the printed material (pictures) used in the instruction?

The variables of interest, namely, from the first script to the personal characteristics of the participants, as well as the answers concerning the risky situations, were chosen: "Looking at this picture (containing the risky situation), what are the dangers of accidents with children you identify?". In the second script, we used the answers to the question: Looking at the picture again, what can you identify as danger?"

A pre-test of the research instruments was done in the same UBSF with five caregivers of the children who did not participate in the final sample. The aim of this pre-test was to verify the clearness of the questions to the population to whom it was destined, having no intention of validating the research instrument.

During the preparation of the educational materials, two illustrations of a kitchen (Figures 1 and 2) were chosen for the educational intervention. Figure $1 \mathrm{had}$ images of objects and risky situations to burns, falls, and cuts, among other kinds of accidents. Figure 2 had situations of protection and safety.

The illustrations were made available during the Campaign 'Tylenol: child's life in safe house' and were printed in colored ink (to facilitate viewing it), prepared in two A4 paper sheets (one for the risky situation and the other one the safe situation) and plasticized (to facilitate handling).

\section{Selection of the participants of the research}

A poster was fixed in UBSF inviting the population to participate in the educational action and direct approaches were made by the interns of Speech Therapy. An attempt of a partnership with the medical doctor of the institution was also made, so that he could inform the caregivers of the children who were consulted by him about this research. Thus, after the appointment, the doctor of the USBF suggested to the caregivers to look for the intern of Speech Therapy in order to participate in the educational action.

The routine of the institution also allowed that the caregivers were approached by the interns in the waiting room. Thus, in some moments, the interviews happened before the attendances (medical, dental and speech therapy) and in other moments after the appointments.

All the children's caregivers (parents, relatives, etc.) who attended that health care unit at the day and time of the internship were invited to participate in this study. Those who accepted to participate signed an Informed Consent Form. Signing the Informed Consent Form was considered as an inclusion criterion. There were no losses and excluded cases in the sample.

\section{Qualification of the Interns of Speech Therapy}

All the actions of this research were carried out by two interns of the third year of Speech Therapy of a public university of the state of São Paulo, who were taking the curricular internship on Wednesday afternoons.

The qualification of the interns for the development of this action was done by a speech therapist, researcher, and doctoral candidate in education who participates in the Education and Accidents Research Group (EDACl), which at that moment was conducting a teaching activity along with the internship mentioned.

During the internship supervision sessions, the researcher presented written materials about the issue, especially the theoretical frame which demonstrates the correlation between the accidents and Speech Therapy ${ }^{13}$, proposing records and preventive reflections in a notebook, that was called by the interns "Logbook". 
The interns solved their questions with the researcher in presence during the biweekly supervision sessions and they also received feedback as written comments on the Logbook about the results obtained and the proposals of improvement to the actions that were being conducted.

\section{Pre-intervention Moment}

In a first moment, Figure 1 was shown to the children's caregivers individually, with 15 possibilities of accidents. The maximum score that could be reached by all of them was 450 discriminations (30 participants multiplied by 15 possibilities).

The participants were asked to report the existing dangers, through the question: "Looking at this picture, what are the dangers of accidents with children you can identify?" The caregivers' answers were registered by the interns in the Logbook.

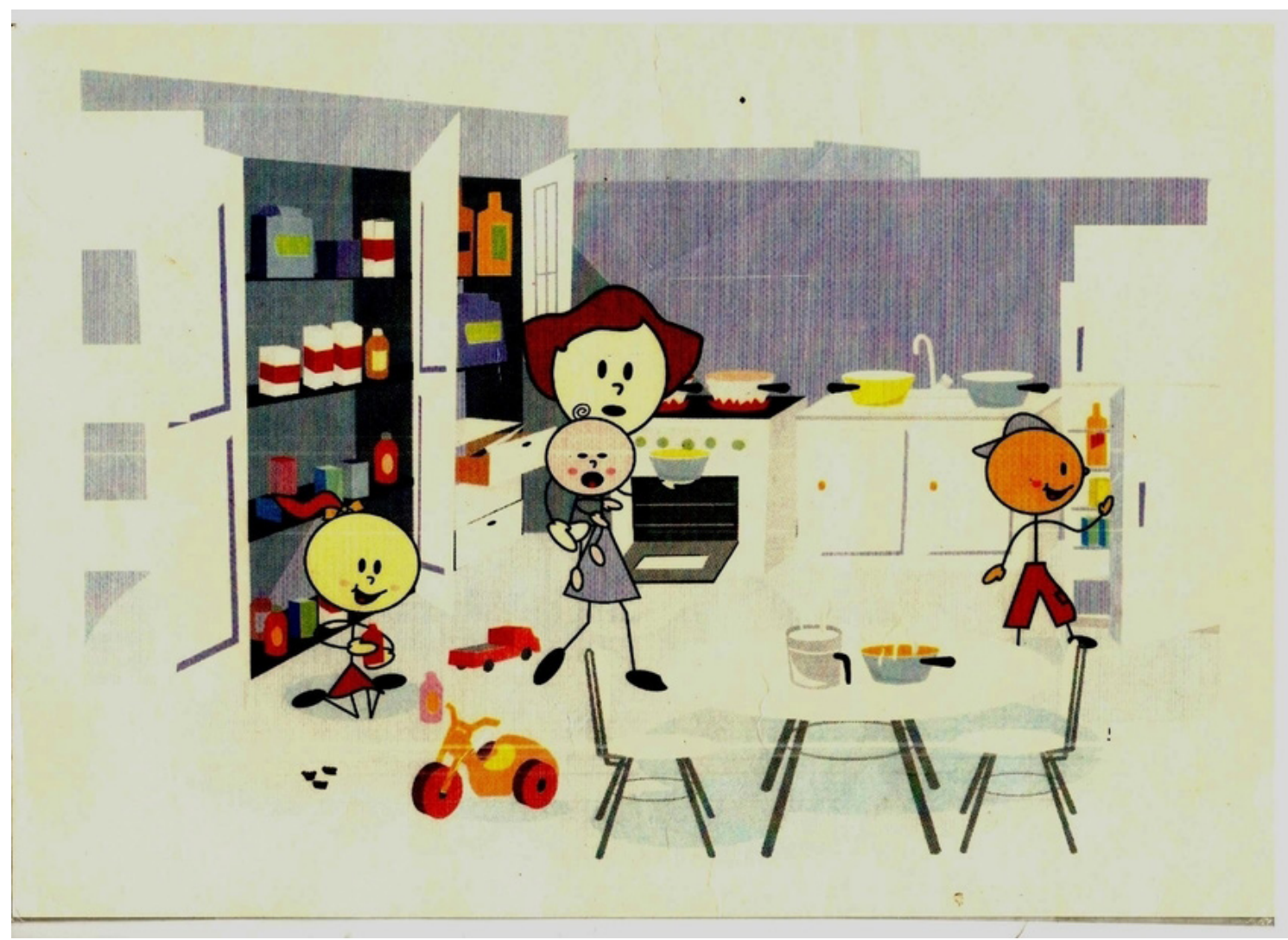

Figure 1. Environment with risk of child accidents 


\section{Intervention Moment}

After the discrimination of the risky situations, under the view of the participants, the educational intervention was done, which was constituted of an explanation of all the risky situations for child accidents contained in the figure, in a dialogized way, offering an opportunity for questions. After that, Figure 2 was shown, with safe situations (without risks of accidents), highlighting the difference between a dangerous and a safe environment.

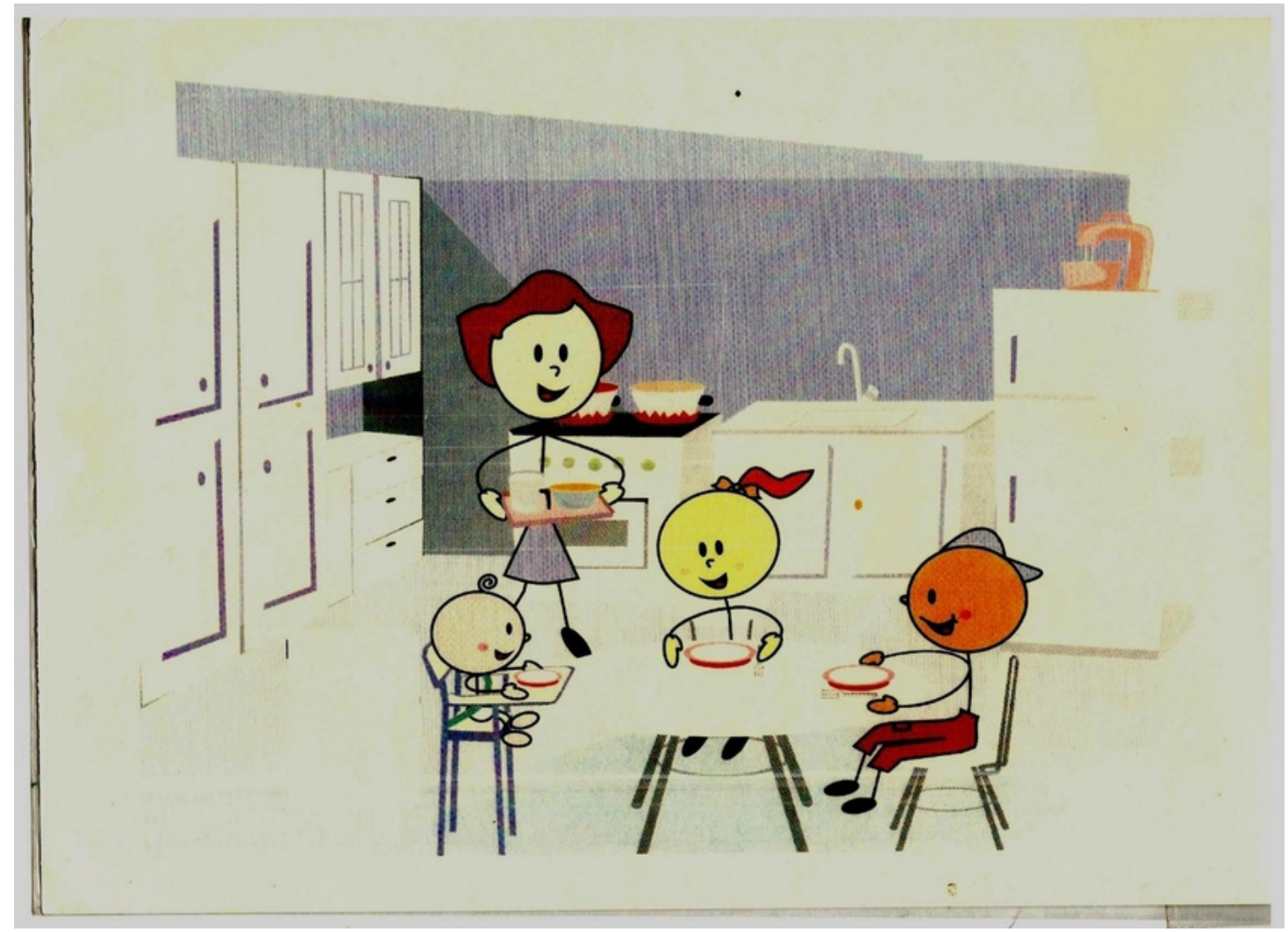

Figure 2. Environment with protection against child accidents

\section{Post-intervention Moment}

Figure 1 was shown again and the participants were asked to indicate the dangers, based on the information dealt in the educational action. The following question was asked: "Looking at the picture again, what can you identify as a risk?" The reports were registered again in the Logbook. Each educational intervention lasted between 10 and 20 minutes.

The information obtained was registered in two columns (pre- and post-) and analyzed individually according to the speech of each participant. The speeches were categorized according to the International Classification of Diseases (ICD 10). The categorization that was done was evaluated by two judges experienced in research of the area of health, having accordance of $96 \%$.
In order to compare the participants' scores in preand post-intervention, the Wilcoxon Test was used. In order to compare the scores between the types of accidents, the Proportion Test was used. The level of significance adopted was $a=0.05$. The results which were considered statistically significant were the ones of the tests which presented a less or equal to 0.05 .

\section{RESULTS}

\section{Characterization of the participants}

30 children's caregivers who attended UBSF participated in this study. Most of the sample were female (93.4\%), $46.7 \%$ were married, $53.7 \%$ were housewives and $43.4 \%$ had incomplete fundamental school education, according to Table 1. 
Table 1. Characterization of the participants

\begin{tabular}{lc}
\hline Sexo & \\
Females & $93.4 \%$ \\
Males & $6.6 \%$ \\
\hline Background & \\
Incomplete Fundamental School & $43.4 \%$ \\
Complete Fundamental School & $23.4 \%$ \\
Complete High School & $10.0 \%$ \\
Supplementary School & $10.0 \%$ \\
Incomplete High School & $3.3 \%$ \\
Complete Higher Education & $3.3 \%$ \\
Illiterate & $3.3 \%$ \\
\hline Marital status & \\
Married & $46.7 \%$ \\
Single & $33.3 \%$ \\
Cohabiting & $10.0 \%$ \\
Divorced & $10.0 \%$ \\
\hline Profession & \\
Housewife & $53.4 \%$ \\
Maid & $16.8 \%$ \\
Student & $10.0 \%$ \\
Screen printer & $3.3 \%$ \\
Salesperson & $3.3 \%$ \\
Self-employed & $3.3 \%$ \\
Auxiliary of production & $3.3 \%$ \\
Machine operator & $3.3 \%$ \\
\hline
\end{tabular}

Source: elaborated by the authors.
The participants attended the health care unit mainly for medical consultation (56.7\%). Besides, they were after medicine (6.7\%) and to weigh the children (6.7\%). They reported as reasons for going to the unit having preventive exam (3.3\%), taking pregnancy test (3.3\%) and follow-up consultation (3.3\%).

\section{Results related to the kinds of accidents}

The analysis of the kinds of accidents mentioned by the participants allowed rating between WOO and X59, according to the ICD 10. The results are shown in Table 2

The results showed that before the educational action the caregivers identified 187 situations of child accidents and after the intervention they identified 215 dangers. According to the Proportion Test, the statistically significant change was related to "Accidental poisoning (intoxication) by exposure to other harmful chemicals and to those not specified", represented by ICD X49 and $a=0.0292$. Another change that was close to the significance was the "Impact caused by object thrown, projected or falling", ICD W2O and $a=0.0642$.

Table 2. Distribution of the kinds of accidents discriminated by the participants

\begin{tabular}{|c|c|c|c|c|c|c|}
\hline \multirow{2}{*}{$\begin{array}{c}\text { Categories } \\
\text { of ICD } 10\end{array}$} & \multirow{2}{*}{ Description of the category ICD 10} & $\mathbf{N}$ & $\%$ & $\mathbf{N}$ & $\%$ & \multirow{2}{*}{$\begin{array}{c}\text { Test of } \\
\text { Proportion }\end{array}$} \\
\hline & & \multicolumn{2}{|c|}{ Pre } & \multicolumn{2}{|c|}{ Post } & \\
\hline W01 & Fall at the same level by slide, stumble, or wrong step & 12 & 6.4 & 14 & 6.5 & 0.4838 \\
\hline W07 & Fall from a chair & 6 & 3.2 & 5 & 2.3 & 0.7100 \\
\hline W20 & Impact caused by an object thrown, projected, or falling & 19 & 10.2 & 33 & 15.3 & 0.0642 \\
\hline W23 & Tight, picked, compressed, or crushed inside or between objects & 1 & 0.5 & 0.0 & 0.0 & 0.9995 \\
\hline W26 & Contact with knife, sword, or dagger & 13 & 7.0 & 19 & 8.8 & 0.2530 \\
\hline W45 & Penetration of strange body or object through the skin & 1 & 0.5 & 1 & 0.5 & 0.5000 \\
\hline W79 & Inhalation and ingestion of food causing obstruction of respiratory tract & 1 & 0.5 & 1 & 0.5 & 0.5000 \\
\hline W80 & Inhalation and ingestion of other objects causing obstruction of respiratory tract & 11 & 5.9 & 14 & 6.5 & 0.4019 \\
\hline W83 & Other specified risks to breathing & 0 & 0.0 & 1 & 0.5 & 0.1665 \\
\hline W85 & Exposure to lines of transmission of electric chain & 0 & 0.0 & 1 & 0.5 & 0.1665 \\
\hline $\mathrm{X} 10$ & Contact with hot beverages, food, fat, and cooking oil & 43 & 23.0 & 49 & 22.8 & 0.5190 \\
\hline $\mathrm{X} 15$ & Contact with hot household appliance & 38 & 20.3 & 29 & 13.5 & 0.9660 \\
\hline X44 & $\begin{array}{l}\text { Accidental poisoning (intoxication) by exposure to other drugs, medicine, and } \\
\text { unspecified biologic substances }\end{array}$ & 34 & 18.2 & 28 & 13.0 & 0.9251 \\
\hline X49 & $\begin{array}{l}\text { Accidental poisoning (intoxication) by exposure to other harmful chemicals and } \\
\text { to those unspecified }\end{array}$ & 2 & 1.1 & 9 & 4.2 & 0.0292 \\
\hline X59 & Exposure to unspecified factors & 6 & 3.2 & 11 & 5.1 & 0.1722 \\
\hline TOTAL & & 187 & 100 & 215 & 100 & \\
\hline
\end{tabular}

Source: elaborated by the authors

Caption: ICD: International Classification of Diseases 


\section{Results related to the children's caregivers}

Among the 30 caregivers who participated, 23 $(76.7 \%)$ widened their knowledge/discrimination of the risky situations to child domestic accidents after the educational action and seven (23.3\%) had no change, according to Figure 3 .

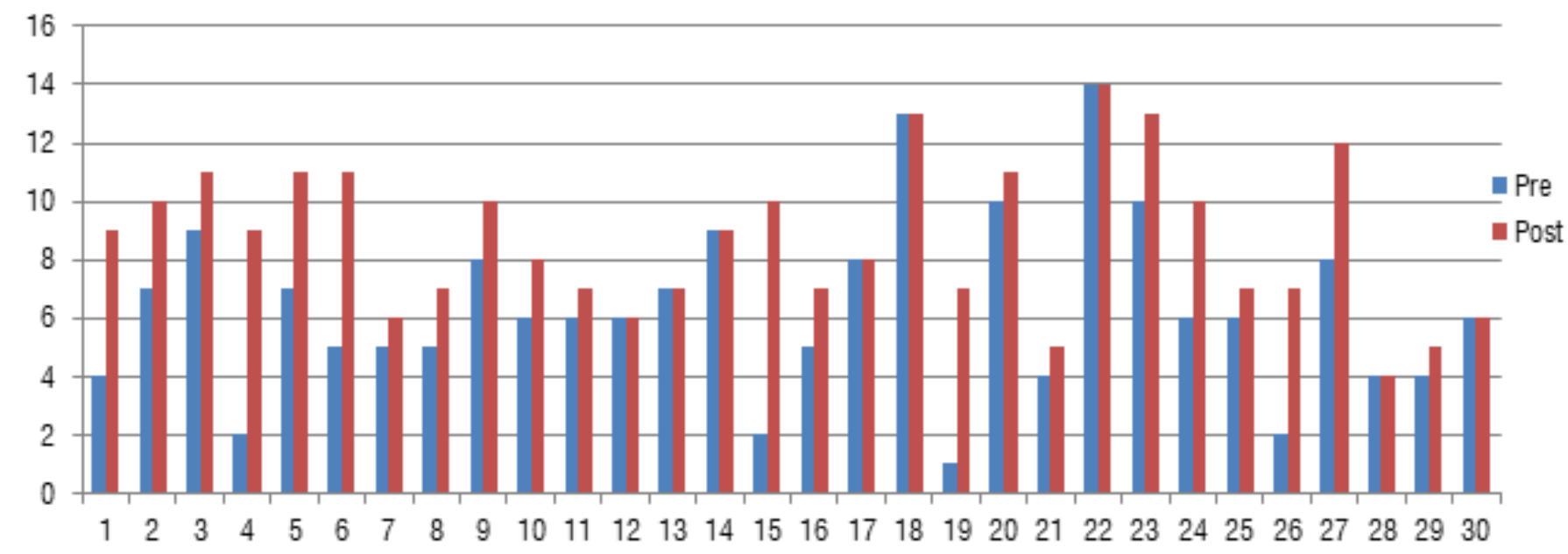

Source: elaborated by the authors

Figure 3. Distribution of participants' knowledge pre- and post-educational intervention

Table 3. Result of the Wilcoxon Test

\begin{tabular}{cccccc}
\hline Moment & $\mathbf{n}$ & Average (SD) & Minimum & Maximum & p \\
\hline Pre & 30 & $6.4(3.04)$ & 1 & 14 & 14 \\
Post & 30 & $8.7(2.60)$ & 4 & 14 & $<001$ \\
\hline
\end{tabular}

Source: elaborated by the authors Caption: $\mathrm{SD}=$ Standard deviation

Before the intervention, the average of risky situations identified was 6.4 and standard deviation of 3.04 . After the educational action conducted by the interns of Speech Therapy, the average of risky situations differentiated increased to 8.7 with standard deviation of 2.60. The Wilcoxon Test demonstrated that the change occurred was statistically significant $(p<0.001)$, according to Table 3.

\section{DISCUSSION}

In this research, carried out in a primary health care unit, the participants were predominantly female. The scientific evidences have shown that women are mainly the ones who take children to health services ${ }^{16}$. The same way, a research conducted in the Pediatric Clinic of the Urgency Hospital of Teresina, Piauí, with caretakers of children who were hospitalized because of domestic accidents, showed that all the companions were women ${ }^{17}$. These two studies showed women's protagonism in accompanying children in health services, therefore they can be the target public of the activities of prevention of child accidents in these services $^{16,17}$.

Concerning the education of the caregivers, there was predominance of incomplete fundamental school education, alike a similar study ${ }^{17}$. The literature ${ }^{18,19}$ classifies the caregivers' low level of education as a predisposing factor to the occurrence of child accidents. A study carried out in the Burn Unit of the Hospital das Clínicas of the University of São Paulo, in Ribeirão Preto, Brazil, showed that 11 among the 13 caregivers of burned children had only the primary level of education complete ${ }^{18}$. The mother's low education was also signaled as a preoccupying factor ${ }^{19}$. 
Still about the characterization of the participants of this study, it was shown that most of them are married. A research conducted with British children showed that the family constitution can be a factor of risk of accidents in childhood ${ }^{20}$. In monoparental families there is more psychosocial risk and the mediation with children can be compromised, therefore these family transitions make accidents more propense ${ }^{20}$.

Most of the caregivers in this research perform activities in their own houses. A study carried out in Teresina, Piauí, showed that most of the caretakers of children who suffered accidents were household people and were dedicated exclusively to domestic chores at the moment of the injury ${ }^{17}$. In Ribeirão Preto, São Paulo, most of the caregivers had also the "Household" occupation ${ }^{18}$. Similar information was identified in a research conducted in São Luís, Maranhão, where most of the children under 10 years old were taken care by mother and/or father at the moment when they had the burn²1.

Concerning the educational material, the printed material used showed to be effective for the intervention. In an intervention carried out with 40 children's relatives under 4 years old, residents of the territory of the basic health care units in a town of the countryside of São Paulo, initial interview, educational action with a folder about burn prevention, and post-intervention interview were done ${ }^{7}$. A week after the action, the results showed an increase in the participants' knowledge ${ }^{7}$.

Another study analyzed the informative potential of an educational action about child burns with the caregivers of children interned in a hospital environment ${ }^{22}$. Questionnaires were applied before and right after the educational action, which included verbal interventions and an educational leaflet, to 37 children's and adolescents' companions in two hospitals of a city in the countryside of the State of São Paulo, Brazil22. The educational action showed a good informational potential for the increase of the percentage of right answers in all the aspects presented ${ }^{22}$.

This research showed that the medical doctor is indicated to participate in the intervention, as he is the most requested professional in the primary health care unit. Thus, this professional could be a partner to the speech therapist in the development of actions of prevention of child accidents in the health care unit ${ }^{10}$, as well as other professionals of the minimal team or the Widened Nucleus of Family Health (NASF-AB). Undergraduates and graduates of academic institutions could be involved, including the ones of Speech
Therapy ${ }^{13}$, what certainly would foster the training of professionals for the prevention of diseases resulting of accidents in childhood and would strengthen the integration between teaching and service.

The interventions directed to the prevention of child accidents must consider the moment of child development and the behavioral habits common to the age, involving counselling families, making changes in the house space and identifying factors of risk $^{23}$. The interventions could initially contemplate the risks to the impact caused by objects thrown or falling in the kitchen or any other place in the house. They could also contemplate accidental poisoning (intoxication) by the exposure to harmful chemicals, which were significantly discriminated by the participants, as it is shown in the Table 2 of the results of this research.

The study presented now was inserted in the activities of curricular internship, which aimed at the capacitation of speech therapists trained to develop educational processes directed to the promotion of health, as well as the prevention of harms which could compromise aspects of the health of the population assisted by the health care unit. The results obtained, or rather, the improvement of the identification of factors of risk, showed that the speech therapist has important contribution to give in basic care, especially in the prevention of harm, corroborating to a study carried out previously ${ }^{13}$. Besides, it demonstrated that the universities have the role of preparing those future professionals to act in the prevention of diseases and health promotion ${ }^{24}$.

New studies could widen the data collection during the intervention by obtaining accounts from the caregivers about real aspects of the house's kitchen where they live. These data could benefit studies which also included follow up and appreciation of the impact that the widening of correct knowledge about intervention in the health care unit could have for the changes in real environment. This information could be complemented by obtaining observational data, making the proposal of paying at least two visits at home, with observation of the kitchen. Future studies could also give away the leaflet with the images used in the intervention, allowing the remembrance of the suggestions and offering the opportunity to share the information with other members who lived in the house.

The action of this study can involve other teaching institutions, involving both students and professors of Speech Therapy and other majors in the area of health. Besides strengthening the integration between 
teaching and service, it may awake the students' interest in actions of harm prevention even during university training. The cooperation with other sectors are also suggestive, especially Education, where children stay for most of their time and the contact with parents/caregivers is made daily.

\section{CONCLUSIONS}

The educational intervention had a positive effect on the participants' perception towards prevention of child domestic accidents. It is not possible to ensure that this change happened exclusively due to the action. In order to allow an analysis of the causality, it would be necessary to conduct a study which could enable controlling all the independent variables, verifying the relations of cause and effect, with a rigorous control.

This study involved interns of Speech Therapy in the actions of prevention of child accidents in primary health care, something that is not usual in college training. The challenge of the continuity of the work remains, involving other students of other groups in formation, as well as other basic health care units in the municipality of the study and other municipalities which host university institutions of Speech Therapy, in order to expand the preventive actions depicted in this work. Besides, the involvement of multiprofessional and intersectorial teams for the strengthening of the Network of action in public health, is suggested.

\section{ACKNOWLEDGEMENTS}

We thank the speech therapist and researcher Gabriela dos Santos Buccini for her support in the statistical analysis.

\section{REFERENCES}

1. Organização Mundial da Saúde. CID-10 Classificação Estatística Internacional de Doenças e Problemas Relacionados à Saúde. 10a rev. São Paulo: Universidade de São Paulo; 1997.

2. Silva TJ, Oliveira VB. Intoxicação medicamentosa infantil no Paraná. Visão Acadêmica. 2018;19(1):51-61. DOI: http://dx.doi.org/10.5380/ acd.v19i1.57576

3. Barcelos RS, Santos IS, Matijasevich A, Barros AJD, Barros F, França GVA et al. Falls, cuts and burns in children 0-4 years of age: 2004 Pelotas (Brazil) birth cohort. Cad. Saúde Pública. 2017;33(2):1-12. DOI: 10.1590/0102-311X00139115
4. Malta DC, Mascarenhas MDM, Silva MMA, Carvalho MGO, Barufaldi LA, Avanci JQ et al. The occurrence of external causes in childhood in emergency care: epidemiological aspects, Brazil, 2014. Ciênc. Saúde Coletiva. 2016;21(12):3729-44. DOI: 10.1590/1413-812320152112.17532016

5. Neves ACM, Mascarenhas MDM, Silva MMA, Malta DC. Perfil das vítimas de violências e acidentes atendidas em serviços de urgência e emergência do Sistema Único de Saúde em capitais brasileiras - 2011. Epidemiol. Serv. Saúde. 2013;22(4):587-96. http://dx.doi.org/10.5123/ S1679-49742013000400005

6. Xavier-Gomes LM, Rocha RM, AndradeBarbosa TL, Silva CSO. Descrição dos acidentes domésticos ocorridos na infância. O Mundo da Saúde. 2013;37(4):394-400. DOI: 10.15343/0104-7809.2013374394400

7. Gimeniz-Paschoal SR, Pereira DM, Nascimento EM. Effect of an educative action on relatives' knowledge about childhood burns at home. Rev. Latino-Am. Enfermagem. 2009;17(3):341-6. DOI: http://dx.doi. org/10.1590/S0104-11692009000300010

8. Andretta IB, Cancelier ACL, Mendes C, Branco AFC, Tezza MZ, Carmello FA et al. Perfil epidemiológico das crianças internadas por queimaduras em hospital do sul do Brasil, de 1998 a 2008. Rev Bras Queimaduras. 2013;12(1):22-9.

9. Meurer BE, Goldfeder EM, Luchesi KF. Stomatognathic functions and face and neck burns: systematic review. Distúrb. Comum. 2018;30(3):464-74.

10. Waksman RD, Blank D. Prevenção de acidentes: um componente essencial da consulta pediátrica. Resid Pediatr. 2014;4(Supl1):S36-S44. https://doi. org/10.25060/residpediatr

11. Amaral ACS, Pascoan DM, Costa JA. Acidentes domésticos infantis: percepção e ações dos profissionais de saúde da urgência e emergência. Serv. Soc. \& Saúde. 2017;16(2):171-88. DOI: http:// dx.doi.org/10.20396/sss.v16i2.8651461

12. Nascimento EN, Gimeniz-Paschoal SR, Sebastião LT. Inter-sector actions to prevent accidents in children education: teacher's assessments and students' knowledge. J. Hum. Growth. Dev. 2013;23(1):99-106.

13. Nascimento EN, Gimeniz-Paschoal SR. Os acidentes humanos e suas implicações fonoaudiológicas: opiniões de docentes e 
discentes sobre a formação superior. Ciênc. Saúde Coletiva. 2008;3(Supl 2):2289-98.

14. Hochman B, Nahas FX, Oliveira Filho RS, Ferreira LM. Desenhos de pesquisa. Acta Cir. Bras. 2005;20(2):2-9.

15. Brasil. Ministério de Planejamento, Orçamento e Gestão. Instituto Brasileiro de Geografia e Estatística 2017. [cited 2018 Nov 17]. Available from: https://www.ibge.gov.br/estatisticas-novoportal/ por-cidade-estado-estatisticas.html?t= destaques\&c $=3529005$.

16. Durães MRP, Toriyama ATM, Maia LFS. O conhecimento dos pais sobre como proceder diante de acidentes domésticos. Recien Rev Cient Enferm. 2012;2(6):5-14.

17. Silva MF, Fontinele DRS, Oliveira AVS, Bezerra MAR, Rocha SS. Determining factors of domestic accidents in early childhood. J. Hum. Growth Dev. 2017;27(1):10-8.

18. Vendrúsculo TM, Balieiro CRB, EchevarríaGuanilo ME, Farina Junior JÁ, Rossi LA. Burns in the domestic environment: characteristics and circumstances of accidents. Rev. Latino-Am. Enfermagem. 2010;18(3):444-51.

19. Martins CBG. Acidentes e violências na infância e adolescência: fatores de risco e de proteção. Rev Bras Enferm. 2013;66(4):578-84.

20. O'Connor TG, Davies L, Dunn J, Golding J. Distribution of accidents, injuries, and illnesses by family type. Pediatrics. 2000;106(5):E68.

21. Rocha Neta AP, Maciel SM, Lopes MLH, Sardinha AHL, Cunha CLF. Perfil dos acidentes por queimaduras em crianças menores de dez anos burn accident profile in children under the age of ten years. SANARE. 2014;13(1):41-7.

22. Gimeniz-Paschoal SR, Nascimento EN, Pereira DM, Carvalho FF. Ação educativa sobre queimaduras infantis para familiares de crianças hospitalizadas. Rev. paul. Pediatr. 2007;25(4):331-6. http://dx.doi. org/10.1590/S0103-05822007000400006

23. Barcelos RS, Del-Ponte B, Santos IS. Interventions to reduce accidents in childhood: a systematic review. J Pediatr. 2018;94(4):351-67. https://doi. org/10.1016/j.jped.2017.10.010

24. Fernandes TL, Nascimento CMB, Sousa FOS. Analyzing the functions of speech therapists of NASF in Recife Metropolitan Region. Rev. CEFAC. 2013;15(1):153-9. 